\title{
Desain Pemberitaan Injil Berbasis Pengenalan Budaya Suku Jawa (Studi Kasus Keluarga Suk di Surakarta)
}

\author{
Soleman Kawangmani \\ Sekolah Tinggi Teologi Gamaliel Surakarta \\ Korespondensi: solemankawangmani@yahoo.co.id
}

\begin{abstract}
Abstrak: Pemberitaan Injil selalu berhadapan dengan budaya pendengar. Pengenalan budaya dan pemanfaatannya sebagai jembatan komunikasi akan mengefektifkan pemberitaan Injil. Sebaliknya, pengabaian budaya dapat mengakibatkan penolakan atau penerimaan dan penghayatan Injil yang sinkretis. Tujuan penelitian ini yaitu menemukan suatu desain pemberitaan Injil berbasis pengenalan budaya rumpun keluarga bersuku Jawa. Penelitian ini menggunakan pendekatan kualitatif dengan metode studi kasus. Pengumpulan data melalui wawancara mendalam dan pengataman kepada keluarga Suk yang bersuku Jawa di Surakarta dan studi pustaka. Peneliti menemukan worldview keluarga Suk sebagai inti budaya yaitu animisme. Untuk menjangkau keluarga suku Jawa berorientasi keagamaan animisme dengan Injil, peneliti mengusulkan suatu "Desain Pemberitaan Injil-6P", terdiri dari enam komponen yaitu persiapan penginjil; 'dambaan keselamatan, hidup bahagia dan tenteram' sebagai point of contact Injil dan budaya, pentahapan isi berita Injil, pelaksanaan pemberitaan Injil, pentingnya motivasi kasih, doa dan pertolongan Roh Kudus, serta pemuridan korektif sebagai basis pelayanan lanjutan. Keenam komponen desain ini harus diintegrasikan dalam pelaksanaannya.
\end{abstract}

Kata kunci: budaya, desain, pemberitaan Injil, suku Jawa, worldview

Abstract: The preaching of the gospel is always dealing with the culture of the listener. The introduction of culture and its use as a communication bridge will make the preaching of the gospel more effectively. On the other hand, cultural neglect can lead to rejection or acceptance and a syncretic living of the gospel. The purpose of this study is to find a design for preaching the gospel based on the introduction of Javanese family culture. This research uses a qualitative approach with a case study method. Collecting data through in-depth interviews and observations of the Javanese Suk family in Surakarta and literature study. The researcher found the worldview of the Suk family as the core of culture, namely animism. To reach Javanese families with animistic religious orientation with the Bible, the researcher proposes a "Gospel Preaching Design-6P", consisting of six components, namely preparation of evangelists; 'desire for salvation, a happy and peaceful life' as a point of contact with the Gospel and culture, phasing out the contents of the gospel message, carrying out the preaching of the gospel, the importance of love motivation, prayer and the help of the Holy Spirit, as well as corrective discipleship as the basis for continued ministry. These six design components must be integrated into their implementation.

Keywords: culture, design, gospel preaching, Javanese, worldview 


\section{PENDAHULUAN}

Komunikasi Injil selalu berhadapan dengan budaya pendengar. Pengabaian pengenalan budaya dapat berdampak berita Injil menjadi asing lalu ditolak oleh pendengar atau Injil diterima namun dihayati secara sinkretis. ${ }^{1}$ Karena itu penginjil perlu mengenali budaya pendengar demi penerimaan Injil yang alkitabiah.

Budaya berkenaan dengan struktur kebiasaan yang kompleks dan asumsi-asumsi yang mendasarinya untuk mengatur kehidupan manusia. Budaya terdiri dari pola perilaku manusia pada bagian permukaan dan pandangan dunia (worldview) pada tingkatan terdalam. Worldview merupakan inti budaya dan bagian terpenting dari keseluruhan hidup seseorang, dimana terdapat struktur asumsi-asumsi atau keyakinan-keyakinan dasar, nilai-nilai dan keterikatan dimana olehnya seseorang menafsirkan realitas ini dan berperilaku. ${ }^{2}$ Worldview juga merupakan keseluruhan respon masyarakat terhadap dunia dimana mereka berada. ${ }^{3}$ Keseluruhan respon yang dimaksud dapat pula berarti cara orang melihat atau memahami dunianya, sebagaimana mereka mengetahuinya. ${ }^{4} \quad$ Dunia yang dimaksud mencakup manusia dan sesamanya, alam semesta, ciptaan berwujud dan tidak berwujud, dan manusia dengan yang supranatural. Jadi, worldview merupakan model penjelasan terhadap apa yang dianggap sebagai realitas dan seterusnya menjadi dasar bagi setiap tindakan.

Budaya dan agama tidak dapat dipisahkan. Agama berkenaan dengan kepercayaan dan keyakinan manusia dimana di dalamnya terdapat antara lain nilai-nilai, norma, ajaran, sistem ritus dan upacara-upacara serta umat atau kesatuan

${ }^{1}$ Timotius Haryono and Attilovita Attilovita, "Model Komunikasi Kabar Keselamatan Kepada Aluk To Dolo Di Tana Toraja," Fidei: Jurnal Teologi Sistematika dan Praktika 4, no. 1 (2021): 62

${ }^{2}$ Charles H Kraft, Antropology of Chistian Witness (Maryknol New York: Orbis Books, 1996), 52.

${ }^{3}$ Paul G. Hiebert, Cultural Antropology, (Grand Rapids Michigan: Baker Book House, 1983), 356.

${ }^{4}$ David J Hasselgrave, Communicating Christ CrossCulturally (Malang: Literatur SAAT, 2013), 125. sosial. $^{5}$ Hal ini berarti agama dapat menjadi sumber nilai-nilai bagi kebudayaan. Nilai-nilai agama itu dapat mengisi worldview sebagai inti budaya. Sebagaimana dikatakan oleh Paul Hiebert bahwa worldview menyediakan bagi seseorang dengan asumsi-asumsi dasar mereka tentang realitas. Agama menyediakan bagi mereka isi spesifik tentang realitas, menyangkut pola penggambaran seseorang tentang alam semesta dan hubungan-hubungan antara manusia dengan segala sesuatu. Sebaliknya melalui ekspresi budaya dapat dikenal dan dinalar penghayatan keagamaan seseorang. ${ }^{6}$ Jadi relasi agama dan budaya sangat erat.

Pelaksanaan amanat penginjilan kepada seluruh suku bangsa (Mat. 28:18-20), harus sungguh-sungguh memperhatikan eratnya hubungan agama dan budaya. Langkah awal yaitu upaya penginjil mengenal bentuk-bentuk budaya, mencari tahu arti dan fungsinya serta menemukan worldview sasaran pemberitaan Injil. Pengenalan worldview sangat penting untuk mendesain pemberitaan Injil yang kontekstual, ${ }^{7}$ termasuk di dalamnya untuk menjangkau suku Jawa.

Berdasarkan hasil penelusuran peneliti ada beberapa artikel jurnal ilmiah teologi berkenaan dengan isu penginjilan dalam keanekaragaman budaya Indonesia, namun secara khusus untuk suku Jawa sejauh ini sangat terbatas. Ada dua kajian terkait. Pertama, Krido Siswanto dalam artikelnya berjudul, "Perjumpaan Injil Dan Tradisi Jawa Timuran Dalam Pelayanan Misi Kontekstual," dengan metode etnografi menyimpulkan bahwa perjumpaan antara Injil dan tradisi Jawa Timuran perlu meniadakan sinkretisme, mengubah makna budaya yang ada dengan makna baru dari isi Injil. ${ }^{8}$ Kedua, artikel Efi Nurwindayani berjudul "Memperkenalkan

\footnotetext{
${ }^{5}$ Koentjaraningrat, Kebudayaan Mentalitas Dan Pembangunan (Jakarta: PT Gramedia, 2002), 144-149.

${ }^{6}$ Hiebert, Cultural Antropology, 371-372.

${ }^{7}$ David Eko Setiawan, "Menjembatani Injil Dan Budaya Dalam Misi Melalui Metode Kontektualisasi," Fidei: Jurnal Teologi Sistematika dan Praktika 3, no. 2 (2020): 160 .

${ }^{8}$ Krido Siswanto, "Perjumpaan Injil Dan Tradisi Jawa Timuran Dalam Pelayanan Misi Kontekstual," Evangelikal: Jurnal Teologi Injili dan Pembinaan Warga Jemaat 1 , no. 1 (2017): 61 .
} 
Kerajaan Allah Untuk Suku Jawa” menggunakan metode studi literatur menghasilkan gagasan 'mangayu hayuning bawana' dan 'pengharapan kehadiran Ratu Adil' sebagai cara untuk memperkenalkan Kerajaan Allah kepada suku Jawa. $^{9}$

Menurut peneliti, analisis Krido Siswanto belum menyentuh worldview suku Jawa. Sedangkan model sintesis Efi Nurwindayani belum dikuatkan oleh data lapangan. Data-data literatur di satu pihak belum tentu mencerminkan situasi terkini. Pada pihak lain budaya tidak terbebas dari perubahan yang terjadi dalam ruang dan lintasan waktu. Selain itu interaksi antara agama yang diakui negara (formal) dan suku Jawa tentu juga akan membawa variasi penghayatan yang bisa berbeda antara sekelompok orang suku Jawa tertentu dengan kelompok suku Jawa lainnya, sekalipun memiliki agama formal yang sama. Penelitian ini berupaya mengumpulkan data lapangan dalam situasi terkini dengan melakukan studi kasus praktik ritual satu keluarga besar suku Jawa, kemudian menganalisis pandangan dunianya dan diakhiri dengan merumuskan suatu desain pemberitaan Injil yang kontekstual. Masalah dalam penelitian ini yaitu bagaimana desain pemberitaan Injil berbasis pengenalan budaya suku Jawa melalui studi kasus kepada keluarga Suk di Surakarta? Tujuan penelitian yaitu menemukan suatu desain penginjilan kontekstual untuk menjangkau suku Jawa. Manfaat penelitian yaitu memberi kontribusi teoritis berupa alternatif desain penginjilan dalam konteks budaya suku Jawa dan memberi inspirasi praktis bagi para pemberita Injil dalam menganalisis budaya suku-suku tertentu dan menjangkaunya secara kontekstual bagi Yesus Kristus.

\section{METODE}

Penelitian ini menggunakan pendekatan kualitatif dengan metode studi kasus. Riset studi kasus mengeksplorasi kehidupan nyata dalam

${ }^{9}$ Efi Nurwindayani, "Memperkenalkan Kerajaan Allah Untuk Suku Jawa," PASCA: Jurnal Teologi dan Pendidikan Agama Kristen 17, no. 1 (2021): 40. setting kontemporer, sistem terbatas (kasus atau beragam kasus) dengan menggunakan aneka cara mendapatkan sumber informasi, dan diakhiri dengan penjelasan tentang makna dari dari kasus tersebut. ${ }^{10}$ Dalam riset ini peneliti berinteraksi dengan satu keluarga besar bersuku Jawa di Surakarta yaitu keluarga Suk. Peneliti melakukan wawancara mendalam dan pengamatan kepada Suk (kakek dalam suatu keluarga besar yang memiliki saudara kandung beserta keluarganya, anak, cucu, cicit, dan para orangtua dari menantunya), Sur (salah satu anak dari Suk yang telah berkeluarga dan memiliki 3 orang anak dan anak-anaknya juga telah berkeluarga dan juga telah memiliki keturunan) dan Ani (salah satu anak dari ibu Sur yang juga sudah berkeluarga dan memiliki 3 orang anak). Penelitian dilakukan pada bulan Mei-September 2021. Wawancara dan pengamatan dilakukan terhadap praktik ritual yang dilakukan oleh keluarga besar Suk sampai saat ini. Sedangkan untuk memperoleh kedalaman pemahaman peneliti tentang makna ritual yang dilakukan, peneliti menggunakan dukungan pustaka, "Upacara Daur Hidup Daerah Jawa Tengah." ${ }^{11}$ Setelah data lapangan terkumpul, peneliti kemudian melakukan analisis worldview dengan mengacu kepada pandangan David J. Hesselgrave mencakup konsep tentang supranatural, manusia dan alam semesta serta konsep waktu ${ }^{12}$ dan dukungan pustaka lain yang relevan. Selanjutnya peneliti memanfaatkan hasil-hasil analisis worldview dalam studi kasus ini sebagai acuan dalam mendesain pemberitaan Injil yang kontekstual kepada keluarga suku Jawa.

\section{PEMBAHASAN}

\section{Potret Budaya Keluarga Suk}

Potret budaya keluarga Suk diperoleh peneliti dari tiga orang partisipan. Partisipan

${ }^{10}$ John W Creswell, Penelitian Kualitatif Dan Desain Riset Memilih Di Antara Lima Pendekatan (Yogyakarta: Pustaka Pelajar, 2015), 135.

${ }^{11}$ Upacara Daur Hidup Daerah Jawa Tengah (Semarang: Depdikbud, 1984), 13-55.

${ }^{12}$ Hasselgrave, Communicating Christ Cross-Culturally, 128-129. 
pertama dalam penelitian ini adalah Suk, berumur 94 tahun, pensiunan PT Pelayaran Nasional (PELNI). Suk memiliki 7 saudara kandung. Saudara-saudara kandung telah beranak cucu. Suk sendiri memiliki 2 anak. Keduanya sudah menikah dan juga memiliki anak-anak (alias cucu bagi Suk). Para cucunya menikah dan memberikan cicit bagi Suk. Suk berpendidikan setingkat SMA. Rumpun keluarga ini menjadi besar karena ditambah dengan para orang tua dari menantu-menantunya. Partisipan kedua yaitu Sur, sebagai anak pertama dari Suk, saat ini berusia 70 tahun, berpendidikan Diploma III dan berprofesi sebagai ibu rumah tangga karena fokus merawat anak-anak. Sur memiliki 3 anak yang sudah menikah, bekerja dan memiliki anak-anak. Partisipan ketiga yaitu Ani, sebagai anak ke-3 dari Sur, kini berusia 37 tahun, pendidikan Sarjana, memiliki 2 anak dan berprofesi sebagai ibu rumah karena fokus mengasuh anak-anak. Semua rumpun keluarga Suk memiliki rumah permanen, berlantai keramik dan dilengkapi perabot rumah tangga yang relatif mewah sehingga dapat dikatakan bahwa keluarga besar Suk tergolong kelas ekonomi menengah. Semua partisipan beragama formal yaitu Islam. Mereka berupaya melaksanakan kewajiban agamanya. Semua anggota keluarga hidup rukun dan harmonis baik dalam keluarga maupun dengan sesama tanpa membeda-bedakan status sosial, suku, ras dan agama. Keluarga Suk selalu aktif dalam kegiatan arisan yang dirancang berdasarkan kekerabatan keluarga bernama Keluarga Dungpani.

Suk, Sur dan Ani memaparkan berbagai praktek ritual. Praktik-praktik ritual dilakukan oleh Suk bersama rumpun keluarga besar termasuk anaknya yaitu Sur dan saudarinya. Sur melihat, merasakan dan terlibat dalam mempersiapkan berbagai perlengkapan ritual yang dilakukan ayahnya (Suk). Ketika Sur sudah berkeluarga, Suk selalu mengingatkan agar Sur harus melakukan ritual-ritual yang pernah dilakukannya demi kebaikan keluarga. Hal yang sama dilakukan oleh Sur kepada anak yaitu Ani dan dua saudara Ani yang lain. Praktek ritualritual itu diwariskan dari ayah ke anak dan ke cucu serta dilakukan terus-menerus hingga saat ini. Sekalipun diakui bahwa masa pandemi Covid-19 cukup memengaruhi frekuensi pertemuan antar keluarga dan praktik ritual tertentu secara bersama-sama, namun mereka tetap berusaha melakukannya pada basis keluarga masing-masing. Aneka ritual yang masih dilakukan dipaparkan berikut ini.

Pertama, Mitoni atau Tingkeban. Ritual ini dilaksanakan ketika usia kehamilan tujuh bulan. Mitoni artinya tujuh sesuai umur kandungan. Ibu hamil mengenakan kebaya (Jawa: jarik), kemudian harus berganti pakaian sebanyak tujuh kali. Dalam ritual ini keluarga menyediakan aneka sesaji berjumlah serba tujuh. Upacara ini dipimpin oleh dukun laki-laki (modin). Sesaji (sajen) sebagai korban ditujukan kepada arwah leluhur dan berbagai makhluk halus dengan harapan agar ibu dan bayi yang dikandung selamat dan terbebas aneka malapetaka.

Kedua, Brokohan, Puputan, Sepasaran dan Selapanan. Selamatan brokohan dilaksanakan menandai bayi sudah lahir dengan selamat melalui pertolongan dukun bayi. Keluarga juga memperlakukan ari-ari dengan cara yang telah diatur yaitu ari-ari si bayi dimasukkan ke dalam kendi, kemudian diberi pasir, kertas, alat tulis, benang, jarum jahit dan selanjutnya dikubur. Bila anaknya laki-laki maka ari-ari di kubur di depan rumah bagian tengah, sedang bila anak perempuan, ari-ari di kubur di depan rumah bagian samping kiri atau kanan. Di atas tempat pekuburan ari-ari biasanya diberi penerangan (lampu). Ari-ari dikubur dengan iringan doa. Puputan dilaksanakan setelah tali pusar bayi putus (puput puser). Upacara sepasaran dilaksanakan sesudah bayi berumur lima hari. Adapun upacara selapanan dilaksanakan setelah bayi berumur tigapuluh hari. Keluarga menyiapkan aneka sajen. Upacara juga dipimpin oleh seorang dukun. Praktik ritual ini sebagai bakti keluarga kepada adat istiadat dan nenek moyang. Tujuannya agar bayi sejak lahir hingga pertumbuhannya selalu mendapat keselamatan, demikian juga ayah dan ibunya sekeluarga, dan dalam pertumbuhan selanjutnya dijauhkan dari musibah akibat kekuatan gaib dan makhlukmakhluk halus yang jahat. 
Ketiga, Sunatan/Supitan dan Sukeran. Upacara ini mengantar anak laki-laki memasuki masa dewasa. Supitan dilakukan oleh dukun selam (bong supit) dan juga para pinisesepuh (orangtua) di lingkungan terdekat. Ketika Supitan, keluarga juga melaksanakan selamatan dan menaikkan doa-doa dengan tujuan untuk menolak bencana yang akan mengancam kehidupan si anak. Sementara untuk anak perempuan diadakan ritual selamatan ketika mengalami menstruasi pertama. Sehari sebelum selamatan, anaknya diberi minum ramuan tradisional yaitu jamu. Selanjutnya mendapat siraman air kembang. Keluarga juga mempersiapkan sajen yang terdiri dari berbagai jenis sayuran. Demikian pula ketika anak perempuan berusia 17 tahun diadakan selamatan Sukeran dan memanjatkan doa demi keselamatan dan kesehatan anak serta pemberitahuan bahwa anak-anak sudah dewasa.

Keempat, Midodareni. Malam sebelum dilangsungkannya pernikahan diadakan malam midodareni. Keluarga juga menyiapkan segala sesuatu antara lain pakaian pernikahan lengkap menurut adat Jawa yaitu kebaya dan perlengkapannya untuk si wanita, demikian pula pakaian pengantin laki-laki dengan perlengkapannya, termasuk sebilah Keris. Pengantin juga akan mendapat siraman air kembang. Dalam resepsi pernikahan ada upacara serah terima pengantin lelaki ke pihak pengantin perempuan, pengantin pria dan wanita saling melempar daun sirih, menginjak telor dan meminta restu dari orang tua kedua belah pihak (sungkem). Aneka ritual dilaksanakan dengan maksud agar acara pernikahan berjalan lancar, dijauhkan dari aneka gangguan dan halangan serta keluarga baru memperoleh keselamatan dan kebahagiaan.

Kelima, Geblak atau sedekah surtanah. Ritual ini dilaksanakan pada saat seseorang meninggal. Istri Suk (alias ibu kandung Sur) meninggal tahun 1997 dan suami Sur meninggal tahun 2013. Pada peristiwa ini keluarga menyiapkan berbagai perlengkapan untuk perjalanan ke kuburan yaitu kembang, air dalam kendi, uang logam dan payung dan peti jenazah. Ketika peti jenazah diberangkatkan diadakan upacara brobosan dimana semua anggota keluarga berjalan secara membungkuk di bawah peti jenazah. Hal ini maksudkan agar keluarga tidak mengingat lagi yang sudah meninggal. Kemudian seorang ibu tua menyapu jalan dengan sapu lidi beberapa langkah awal sebagai pembuka jalan pemberangkatan peti jenazah. Kemudian kembang bercampur uang logam ditabur sepanjang jalan menuju makam dan juga ditabur di atas makam. Payung juga disiapkan dan ditancapkan di bagian kepala dari kuburan. Setelah upacara pemakaman, keluarga kemudian melaksanakan ritual peringatan kematian mulai dari tiga hari, tujuh hari, 40 hari, 100 hari, 1 tahun (mendhak) dan 1000 hari (nyewu). Pada waktu-waktu ini keluarga menyiapkan sajen dan melakukan tabur bunga (nyekar) di kuburan dan berdoa (ngirim donga) dengan maksud agar arwah yang diziarahi itu memberikan berkat.

Keenam, Ruahan. Pelaksanaan ritual ini yaitu saat menjelang bulan puasa. Keluarga biasanya menyiapkan sajen dalam rangka nyekar dan ngirim donga di kuburan anggota keluarga yang meninggal. Setiba di kuburan sajen diletakkan di kuburan yang telah dibersihkan dan ditaburi bunga. Kemudian dupa dibakar dan keluarga menaikkan doa ke arwah yang sudah meninggal disertai harapan agar semua anggota keluarga diberkati dan dijauhkan dari malapetaka akibat gangguan makhluk halus.

Ketujuh, Nyekar dan Ziarah Kubur. Bersihbersih kuburan dan tabur bunga (nyekar) biasa dilakukan keluarga Suk satu minggu sebelum hari Raya Idul Fitri (Lebaran). Saat di kuburan keluarga mengadakan bersih-bersih (resik-resik) kuburan. Disamping itu pada waktu malam menjelang hari raya Idul Fitri keluarga menyiapkan sajen. Selanjutnya dua hari setelah lebaran diadakan lagi bersih-bersih kuburan dan nyekar. Keluarga membawa berbagai benda ke kuburan yaitu tikar, kendi, buah kelapa yang akan dibelah dan ayam jantan yang akan di lepas di kuburan. Sementara di rumah diadakan ibadah (nyatri, tahlilan).

Menurut para partisipan, mereka tidak mengingat secara lengkap bahan-bahan yang digunakan sebagai bahan sajen dan juga arti atau makna ritual-ritual di atas. Namun secara 
keseluruhan tujuan pelaksanaan semua ritual yaitu untuk memperoleh berkat, ketenteraman, keselamatan dan tidak ada halangan atau kesulitan dalam menjalani hidup ini. Menurut Suk, Sur dan Ani semua ini dilakukan demi anak dan keluarga, karena memang tradisinya demikian.

Para partisipan mengakui bahwa dalam pelaksanaan ritual biasanya ada perasaan takut salah ketika menyiapkan bahan sajen baik macam bahan maupun jumlahnya. Demikian pula ada perasaan takut bila berbagai bahan yang diperlukan tidak lengkap dan pelaksanaan tidak sesuai yang digariskan oleh orangtua mereka dahulu. Hal ini akan beresiko bagi keselamatan dan ketenteraman keluarga. Karena itu biasanya keluarga meminta bantuan orang (dukun) yang tahu secara tepat tentang ritual, baik tahap persiapan maupun pelaksanaannya. Keluarga hanya perlu menebus, maksudnya membayar biaya ritual itu kepada dukun. Namun mereka juga mengakui bahwa terkadang terjadi perubahan atau ketidaklengkapan bahan sajen karena kondisi yang tidak memungkinkan, tetapi setidaknya mereka terus melakukannya, termasuk bila harus tanpa bantuan dukun.

\section{Analisis Pandangan Dunia (Worldview)}

David J. Hesselgrave mengajukan suatu pola dalam memahami pandangan dunia agama dan keagamaan sasaran pemberitaan Injil..$^{13}$ Pertama, memahami konsep tentang supranatural, manusia dan alam semesta, karena ketiga pokok inilah yang sering menjadi kandungan pertanyaan manusia. Kedua, memahami ketiga hal di atas dalam kaitan dengan konsep waktu. Faktor waktu sangat penting bagi manusia dalam merumuskan atau meniadakan makna di dalam hidupnya. Hasil analisis terkait pandangan dunia keluarga Suk sebagai inti budaya partisipan dipaparkan berikut ini.

Pertama, pandangan tentang supranatural. Keluarga besar partisipan semua menganut Islam sebagai agama yang diakui oleh negara (formal). Para partisipan berusaha melaksanakan kewajiban agamanya sebagaimana tampak dalam

\footnotetext{
${ }^{13}$ Ibid.
}

melaksanakan ibadah puasa, merayakan Idul Fitri dan kewajiban ibadah lainnya. Para partisipan juga berupaya menghayati agamanya dalam hidupnya. Dipihak lain, mereka juga taat melaksanakan aneka ritual yang diwariskan dari satu generasi ke generasi berikutnya. Ritual warisan orangtua dilaksanakan bertalian juga dengan praktik agama formalnya. Sejatinya ritual adalah suatu ekspresi simbolis dari keyakinan spesifik yang digunakan orang untuk menghasilkan model penjelasan terhadap dunia. ${ }^{14}$ Mencermati penghayatan para partisipan dari pelaksanaan beberapa praktik ritual ditemukan hal berikut ini: Pertama, partisipan dalam menyiapkan upacara selamatan melibatkan dukun (modin), bong supit dan juga para pinisepuh. Walau demikian akhir-akhir ini karena kondisi tertentu pelibatan dukun tidak dilakukan. Artinya telah terjadi percampuran keyakinan antara agama formal dan perdukunan (sinkretisme). Kedua, praktek ritual bersih-bersih kubur, ngirim donga dan nyekar diarahkan atau ditujukan kepada arwah orang tua dan nenek moyang. Ketiga, ada konsep bahwa walaupun seseorang sudah beragama formal tertentu tetapi pasti akan tetap melaksanakan tradisi nenek moyang. Keempat, semua praktek ritual itu dilaksanakan dengan teratur dan benar karena keyakinan bahwa jika tidak demikian ada resikonya. Ketika semuanya dilaksanakan dengan benar maka akan ada berkatnya, sekalipun partisipan tidak memahami secara detail yang dikerjakan atau digunakan. Pokok-pokok temuan ini menyiratkan bahwa sesungguhnya adat istiadat nenek moyang umumnya dilaksanakan tanpa dipahami lagi maknanya. Yakob Tomatala mengatakan bahwa pandangan dunia umumnya diterima tanpa diuji terlebih dahulu atau tanpa dipersoalkan. ${ }^{15}$ Itulah sebabnya para partisipan mewariskan dari satu generasi ke generasi lainnya dan berupaya terus melaksanakan sebaik-baiknya sekalipun hanya dengan alasan bahwa sejak dahulu memang demikian seharusnya.

\footnotetext{
${ }^{14}$ Hiebert, Cultural Antropology, 372-373.

${ }^{15}$ Yakob Tomatala, Pengantar Antropologi
} Kebudayaan: Dasar-Dasar Pelayanan Lintas Budaya (Jakarta: Media Penerbit Kristen, 2007), 107. 
Temuan atas data lapangan ini juga menunjukkan keyakinan partisipan bahwa ajaran dan praktik ritual nenek moyang bersifat universal walaupun isi dan bentuk ajaran berbeda antara seorang dan yang lainnya. Oleh karena itu sekalipun para partisipan sudah menganut agama formal, namun sebagai keluarga bersuku Jawa tetap akan melaksanakan praktik ritual yang diajarkan nenek moyang yaitu menyembah kepada arwah atau roh-roh yang sudah mati. Para partisipan juga percaya bahwa roh-roh yang disembah akan memengaruhi kehidupan keluarganya, pernikahannya dan masa depan anak-anak, hal mana tercermin dari penggunaan air kembang untuk siraman dan ziarah ke tempat-tempat keramat, ngirim donga. Para partisipan mengakui adanya alam roh yang memiliki kekuatan sakti yang mampu menjamin kebahagiaan hidup dan keselamatan manusia, namun dapat juga membawa bencana kerugian, kecelakaan bahkan kematian. Sajen, air kembang dan upacara selamatan merupakan suatu upaya perbuatan bakti kepada roh-roh itu untuk menjamin kebahagiaan hidup mereka. Ekspresi keyakinan akan adanya kuasa roh-roh juga tampak dari pelibatan dukun sebagai pihak yang memahami secara tepat alam gaib (Jawa: kasekten) dan roh-roh.

Fakta agama Islam dapat diterima oleh keluarga Suk, namun dipihak lain praktik ritual dari nenek moyang yang masih terus dilaksanakan membuat keluarga Suk seolah-olah menganut dua agama. Terhadap realitas interaksi antara agama Islam dan orang Jawa, Clifford Geertz menggolongkan orang Jawa atas tiga golongan yaitu Abangan, Santri dan Priyayi. ${ }^{16}$ Golongan Abangan memang berpegang pada ajaran Islam tetapi tidak menjalankan rukun Islam secara totalitas. Mereka tetap melaksanakan aneka ritual selamatan dan tradisi nenek moyang lainnya. Golongan Santri adalah penganut Islam yang patuh dan teratur beribadah. Sedangkan Priyayi adalah golongan cerdik pandai. Berdasarkan penggolongan ini keluarga Suk termasuk dalam golongan Abangan, karena sekalipun beragama Islam

${ }^{16}$ Clifford Geertz, Abangan,Santri,Priyayi Dalam Masyarakat Jawa (Jakarta: Pustaka Jaya, 1983), xxx-xxxii. namun orientasi hidup pada ajaran dan praktik ritual nenek moyang tetap terjaga. Menurut pandangan peneliti agama formal bagi keluarga Suk hanya berfungsi sebagai selubung terhadap orientasi keagamaan sesungguhnya yaitu animisme. Hal ini tampak dari kesungguhan mereka melaksanakan dan mewariskan ritualritual dari leluhur ke generasi-generasi berikutnya dan sikap takut bila tidak melaksanakan semua tradisi itu. Selain itu secara tersirat dapat dikatakan bahwa latar belakang pendidikan tinggi yang dimiliki oleh Sur maupun Ani tidak memberi nilai-nilai rasional atau korektif terhadap praktik penyembahan kepada roh-roh halus. Karena itu sebagaimana pandangan Rachmat Subagya, ${ }^{17}$ disimpulkan bahwa pandangan dunia tentang supranatural dari keluarga Suk yaitu Animisme karena percaya kepada roh-roh halus.

Kedua, Pandangan tentang manusia. Sikap para partisipan yang merasa takut apabila tidak tepat dalam melaksanakan praktik ritual menunjukkan bahwa para partisipan menghayati dirinya sebagai manusia yang memiliki tubuh jasmani tetapi juga memiliki jiwa sehingga dapat berpikir, berkehendak dan merasakan sesuatu. Manusia adalah pribadi yang terbatas dan tidak berdaya dihadapan roh-roh halus. Sekaligus manusia adalah pribadi yang harus berupaya mencari kekuatan dari kuasa-kuasa yang ada di sekitarnya dan memohon pertolongan dari roh-roh. Manusia pada suatu saat akan mati, namun ada kehidupan setelah mati dalam wujud roh-roh itu sebagaimana roh-roh leluhur yang masih bisa dihubungi melalui ritual untuk mempengaruhi manusia yang masih hidup.

Para pastisipan percaya bahwa hidup mereka di dunia sudah diatur sehingga tinggal menjalaninya saja. Manusia tidak terlepas dari totalitas tatanan kosmos. Jadi apabila ada kesukaran dalam alam semesta, maka manusia akan menderita juga. Sebaliknya rasa tenang dan aman setelah melakukan praktik ritual menunjukkan bahwa para partisipan merasa telah hidup menurut kehendak dari roh-roh. ${ }^{18}$

\footnotetext{
${ }^{17}$ Rachmat Subagya, Agama Dan Alam Kerohanian Asli Di Indonesia (Jakarta: Cipta Loka Caraka, 1979), 67.

${ }^{18}$ Soleman Kawangmani, "POLA APOLOGETIKA KONTEKSTUAL UNTUK MEMBERITAKAN KABAR
} 
Menurut Budiono Herusatoto praktik ritual sebagai upaya manusia yang terbatas untuk memuja dan memohon berkat dan perlindungan dari roh yang bersifat baik dan dijauhkan dari gangguan roh yang jahat. ${ }^{19}$

Jadi pandangan dunia para partisipan tentang manusia bahwa manusia adalah pribadi yang memiliki tubuh dan jiwa, terbatas dan tidak berdaya serta menjadi bagian dari alam semesta dan berada di bawah campur tangan yang supranatural yaitu roh-roh.

Ketiga, Pandangan tentang alam semesta. Mencermati berbagai praktik ritual dalam setiap tahapan kehidupan maupun hari-hari besar keagamaan yang dianut para partisipan, tampak bahwa para partisipan menghayati alam semesta ini dikuasai oleh roh-roh. Oleh karena itu setiap praktik ritual tidak lain adalah usaha untuk memengaruhi roh-roh agar alam semesta ini menjadi berkat bagi kehidupan. Hal ini dapat disimpulkan bahwa bagi para partisipan, alam semesta dan manusia itu sederajat berada di bawah campur tangan yang supranatural yaitu roh-roh halus.

Keempat. Pandangan tentang waktu. Mencermati bentuk praktik ritual para partisipan dapat disimpulkan bahwa para partisipan melaksanakan praktik ritual lingkaran hidup. Lingkaran hidup (life cylcle) adalah rangkaian keberadaan dalam kehidupan manusia yang dibagi ke dalam tahap-tahap tertentu dan peralihan dimana terkadang tidak jelas dari tahap satu ke tahap berikutnya dan sering disertai ritual yang dikenal sebagai ritual inisiasi. $^{20}$ Selain itu partisipan juga melakukan selamatan berkenaan dengan hari-hari besar keagamaan dan bulan-bulan besar Jawa. Keteraturan waktu dalam pelaksanaan ritual kepada arwah atau roh-roh leluhur tampak jelas dari ritual kelahiran sampai kematian bahkan ritual sesudahnya yaitu pada hari ketiga, ketujuh, hingga keseribu. Bahkan setelah itu tetap diadakan nyekar serta ngirim donga secara teratur.

BAIK KEPADA SUKU JAWA WONG CILIK,” Jurnal Gamaliel : Teologi Praktika (2019): 65-66.

${ }^{19}$ Budiono Herusatoto, Simbolisme Dalam Budaya Jawa (Yogyakarta: PT Hanindita, 1987), 99.

${ }^{20}$ Tomatala, Pengantar Antropologi Kebudayaan: Dasar-Dasar Pelayanan Lintas Budaya, 146.
Menurut Koentjaraningrat, diantara semua ritual selamatan, ritual lingkaran hidup khususnya yang berhubungan dengan kematian dan saat sesudahnya adalah suatu adat kebiasaan yang sangat diperhatikan dan kerapkali dilaksanakan oleh semua golongan masyarakat Jawa karena penghormatan yang tinggi kepada arwah orang mati. $^{21}$ Semua ritual itu dilaksanakan keluarga Suk dalam rangka memperoleh kebahagiaan dan keselamatan hidup.

Mencermati penghayatan keagamaan tersebut nyata bahwa konsep tentang waktu bagi para partisipan yaitu berorientasi kepada masa lalu yang tertuang dalam tradisi leluhur. Makna kejadian dan perbuatan serta keberadaan masa kini cenderung dinilai berdasarkan konsep dan ukuran masa silam. Selanjutnya hidup kemasakinian dianggap membawa dampak bagi kemasadepanan. Sekalipun demikian, perhatian terhadap faktor waktu tetap kepada masa lampau.

\section{Desain Pemberitaan Injil Berbasis Pengenalan Budaya Suku Jawa}

Firman Allah mengajarkan tiga prinsip utama dalam menyusun desain pemberitaan Injil yang kontekstual dengan budaya penerima Injil yaitu: Pertama, tujuan pemberitaan Injil yaitu untuk menjangkau sebanyak mungkin orang bagi Kristus; Kedua, cara atau metode pemberitaan Injil yaitu kontekstual dengan budaya penerima berita Injil; dan Ketiga, standar pemberitaan yaitu Injil Kristus tetap terjaga kemurniannya (1 Kor. 9:19-22). ${ }^{22}$ Untuk memberitakan Injil secara kontekstual kepada Suk sebagai keluarga suku Jawa yang memiliki memiliki pandangan dunia animisme, peneliti mengusulkan suatu "Desain Pemberitaan Injil6P.” Pemberitaan Injil (PI)-6P merupakan desain penginjilan yang mengintegrasikan enam komponen yaitu: 1) persiapan penginjil; 2) point of contact Injil dan budaya, 3) pentahapan isi berita Injil, 4) pelaksanaan penginjilan,

\footnotetext{
${ }^{21}$ Koentjaraningrat, Manusia Dan Kebudayaan Di Indonesia (Jakarta: Penerbit Djambatan, 1987), 346-347.

${ }^{22}$ Kawangmani, "POLA APOLOGETIKA KONTEKSTUAL UNTUK MEMBERITAKAN KABAR BAIK KEPADA SUKU JAWA WONG CILIK."
} 
5) pentingnya motivasi kasih, doa dan pertolongan Roh Kudus, dan 6) pemuridan korektif sebagai basis pelayanan lanjutan. Uraian keenam komponen sebagai berikut.

\section{Persiapan Penginjil}

Seorang pemberita Injil dalam konteks keluarga suku Jawa yang berpandangan dunia animisme harus sudah percaya Yesus sebagai Tuhan dan Juruselamat serta terus bertumbuh secara rohani menuju kedewasaan di dalam Kristus (Yoh. 3:1-7, 2 Kor. 5:17, Ef. 4:11-16 dan Kol. 2:6-8). Seorang penginjil juga harus sudah mengalami dan senantiasa hidup dalam kepenuhan Roh Kudus yang adalah Roh Kristus sendiri, mengalami manifestasi Roh Kudus dalam dirinya dan pelayanannya serta mengenakan seluruh perlengkapan senjata Allah dalam kehidupan dan pelayanannya setiap hari (Mrk. 16:15-18, Yoh. 14-17, Kis. 1:8, Ef. 6:10-10, 1 Yoh. 4:1-6). Kualifikasi ini sangat penting karena keluarga suku Jawa sudah dan senantiasa hidup dalam pengalaman kuasa-kuasa dan rohroh. Tanpa perlengkapan ini seorang penginjil hanya akan diterima sebagai pembawa ajaran baru atau menerima ajaran Kristen sebatas selubung agama formal baru. Penginjil perlu juga memiliki sikap hormat dan menghargai keluarga-keluarga suku Jawa dengan keunikan ritual budayanya. Demikan pula kesediaan untuk bergaul dan bersikap rukun sebagaimana sikap orang Jawa dimana pada umumnya juga sangat mementingkan kerukunan. Dalam konteks pergaulan, perlu pula sikap tulus dan bijaksana agar dapat membedakan respon keluarga suku Jawa terhadap diri penginjil dan isi berita Injil. Hal ini disebabkan karena penerimaan terhadap penginjil belum tentu beriringan terhadap penerimaan atas isi berita Injil. Dalam hal ini kebergantungan kepada pimpinan dan kuasa Roh Kudus sangat penting karena Roh Kuduslah yang menginsafkan manusia akan keberdosaan dan kebutuhan akan Injil. Roh Kudus juga menolong dalam menyediakan hikmat dan kearifan untuk melayani keluarga suku Jawa kaum untuk mengenal kasih karunia Allah di dalam Kristus bagi mereka.
Point of Contact Injil dan

Budaya Suku Jawa

Efektivitas pemberitaan terwujud bila pemberita Injil memahami budaya penerima berita Injil dan memanfaatkan titik temu (point of contact) Injil dengan budaya penerima Injil. Pemanfaatan titik temu ini secara kreatif akan mengatasi aneka rintangan komunikasi dan secara positif akan mengefektifkan tahapan proklamasi Injil. ${ }^{23}$ Dari analisis worldview, tampak bahwa ada titik temu antara Injil dan budaya keluarga suku Jawa. Dambaan keluarga suku Jawa yang memiliki orientasi keagamaan animisme akan keselamatan, hidup damai dan bahagia dalam campur tangan roh-roh, menemukan jawaban sejati di dalam Yesus Kritus karena Yesus Kristus berkuasa atas alam semesta maupun alam roh dan berkenan mendiami serta hidup bersama setiap orang yang percaya kepada-Nya, memberi keselamatan, hidup bahagia dan damai sejahtera sejati pada masa kini maupun masa yang akan datang.

\section{Pentahapan Isi Berita Injil}

Pemberita Injil perlu mengkontekstualisasikan isi berita Injil yang tidak berubah (kekal) itu sesuai alam pikir, rasa dan bahasa keluarga suku Jawa penganut animisme. Teladan rasul Paulus dalam memberitakan Injil kepada orang Atena dalam Kisah Para Rasul 17:16-34 sangat kontekstual juga bagi alam pikir animisme di lingkungan keluarga suku Jawa. Bertolak dari aneka ritual kepada roh-roh yang tidak dikenal oleh penganut animisme sebagai point of contact, pemberita Injil dapat memulai pentahapan isi berita Injil dalam pemberitaannya. Tahapan awal dari isi berita Injil berkenaan dengan pengenalan akan Allah. Pemberita menjelaskan dan memperkenalkan Allah sebagai pribadi yang berkuasa, pencipta dan pemilik alam semesta, pengatur tatanan kosmos, hakim dan kemudian memperkenalkan Tuhan Yesus (ayat 22-25). Tahapan selanjutnya yaitu karya-karya Allah. Pemberita Injil memberikan penjelasan tentang

${ }^{23}$ Setiawan, "Menjembatani Injil Dan Budaya Dalam Misi Melalui Metode Kontektualisasi." 
karya penciptaan dan pemeliharaan Allah terhadap manusia dalam setiap aspek kehidupan dan tujuan hidup manusia (ayat 26-31). Tahapan berikutnya yaitu panggilan pertobatan. Pemberita Injil menjelaskan berita pertobatan dengan alasan sebagai kehendak Allah (ayat 30, 31). Penginjil dapat pula menjelaskan tentang hari penghakiman dan akibatnya bagi manusia yang tidak mengakui dirinya sebagai manusia berdosa dan tidak mau percaya kepada Allah di dalam Yesus Kristus (ayat 31). Karena hanya di dalam Yesus Kristus ada arti hidup (ayat 28), dan hanya di dalam Yesus Kristus yang telah mati di kayu Salib dan bangkit pada hari yang ketiga itulah tersedia keselamatan yang kekal (ayat 31). Yesus Kristus sebagai hakim berkewenangan menghakimi semua manusia yang hidup tidak berporos pada Allah tetapi pada kuasa-kuasa dan roh-roh atau dewa-dewa (ayat 23). Tahapan berita yang terakhir adalah berkenaan dengan pentingnya respon penganut animisme terhadap berita Injil. Hal ini penting karena hanya respon penerimaan terhadap Yesus Kristus sebagai Tuhan dan Juruselamat serta penguasa alam semesta, maka keselamatan dan kebahagiaan hidup sejati akan dialami manusia masa kini hingga dalam kekekalan kelak di sorga.

\section{Pelaksanaan Pemberitaan Injil}

Sarana komunikasi yang dapat dimanfaatkan yaitu bahasa suku Jawa yang sesuai dengan keluarga Suk. Dalam konteks keluarga suku Jawa tentu sangat efektif bila penginjil berkomunikasi dengan menggunakan bahasa Jawa. Penginjil perlu memiliki sopan santun dan pergaulan yang ramah sebagai kesaksian non verbal untuk meneguhkan berita Injil secara verbal. ${ }^{24}$

Pelaksanaan pemberitaan Injil dapat dilakukan dengan cara dialog komunitas yang bersifat searah dan searus dalam arti bahwa penginjil melaksanakan peran dan panggilannya sebagai pembawa berita Injil (Rm. 10:13-15) dan berupaya memperkenalkan Yesus Kristus kepada keluarga suku Jawa. Pemberitaan Injil dapat pula dilaksanakan dengan memanfaatkan peristiwa-

\footnotetext{
${ }^{24}$ Siswanto, "Perjumpaan Injil Dan Tradisi Jawa Timuran Dalam Pelayanan Misi Kontekstual.”
}

peristiwa syukuran ketika keluarga Suk dikarunia anak dan waktu-waktu kebersamaan lainnya.

Pemberita Injil juga harus mampu mendemonstrasikan kuasa Yesus Kristus sebagaimana yang dijanjikan-Nya dalam Markus 16:15-18 dan Kisah Para Rasul 1:8. Hal ini sangat penting karena penganut animisme selalu berorientasi kepada roh-roh halus, sehingga perlu pelayanan perjumpaan kuasa (power encounter) agar terbebas dari ikatan dengan rohroh halus. ${ }^{25}$ Kemerdekaan dari kuasa si jahat akan menjadi jalan masuk untuk menumbuhkan minat keingintahuannya akan Kristus Sang Pelepas. Hal ini akan berdampak positif dimana Yesus Kristus akan lebih efektif diperkenalkan kepada keluarga suku Jawa, sebagaimana bukti nyata yang terjadi di dalam pelayanan Rasul Paulus di Listra (Kis 14:8-2). Alkitab menyatakan bahwa ketika terjadi mujizat penyembuhan orang yang lumpuh terjadi, maka kaum animisme menyambut Paulus dan Barnabas dengan pernyataan bahwa dewa-dewa telah turun dalam rupa manusia. Momentum ini dimanfaatkan Paulus dan Barnabas untuk memperkenalkan Yesus Kristus kepada orang banyak.

\section{Pentingnya Motivasi Kasih, Doa, dan Roh Kudus}

Pelayanan pemberitaan Injil harus dilandasi dengan kasih Kristus (2 Kor. 5:14-15). Kasih tentu menuntut adanya perhatian dan kerelaan berkorban dalam memberitakan Injil agar keluarga suku Jawa juga memperoleh kesempatan untuk mendengar dan meresponnya. Penginjil juga harus tekun berdoa bahkan berpuasa agar Allah memberi terobosan ilahi demi keselamatan keluarga suku Jawa. (Rm. 1:16-17, 10:1-3). Pemberitaan Injil harus dilaksanakan dalam kebergantungan kepada pimpinan Roh Kudus. Roh Kuduslah yang akan menginsafkan keluarga suku Jawa akan dosa, kebenaran dan penghakiman (Yoh. 16:8-11). Kesadaran keluarga suku Jawa akan keberadaannya sebagai manusia berdosa dan kebutuhannya akan Juruselamat merupakan

\footnotetext{
${ }^{25} \mathrm{Kraft}$, Antropology of Chistian Witness, 452-452.
} 
jalan untuk menyambut berita Injil dengan sukacita. Hanya Roh Kudus yang mampu mengerjakan hal ini di dalam diri keluarga suku Jawa. Hikmat dan kepintaran pemberita Injil tidak akan dapat mewujudkan kesadaran ini, karena memang penginjil hanya berperan sebatas memberitakan Yesus Kristus saja. Oleh karena Roh Kuduslah, seseorang dapat mengakui Yesus Kristus adalah Tuhan (1 Kor. 12:3). ${ }^{26}$

\section{Pemuridan Korektif Sebagai \\ Basis Pelayanan Lanjutan}

Setelah keluarga suku Jawa menyambut Yesus Kristus, perlu dilakukan pelayanan follow up untuk meletakkan dasar Alkitab terhadap isi iman dan peneguhan kebenaran Injil serta menuntunnya untuk bertumbuh dalam Firman dan pimpinan Roh Kudus. Hal ini penting karena warisan pemahaman dan pengalaman yang bersifat animistik harus dikoreksi oleh kuasa Firman melalui pemuridan dan kuasa Roh Kudus. Suatu pemuridan yang bersifat korektif terhadap warisan pemahaman yang lama hanya dapat efektif terjadi bila dilakukan pemuridan berbasis kelompok kecil. Demikian pula perlu ditunjang dengan pilihan kitab dalam Alkitab yang tepat di tahapan awal pemuridan sangat diperlukan. Surat Kolose sangat tepat karena di dalamnya rasul Paulus mengoreksi praktikpraktik ritualisme, asketisme, mistisisme dan penyembahan spekulatif kepada malaikat dan roh-roh angkasa. ${ }^{27}$ Pemuridan korektif akan menghindarkan para petobat baru untuk kembali ke masa lalu atau mencampuradukkan warisan masa lalu dengan kebenaran Injil sehingga terjadi sinkretisme dalam hidupnya. Sebaliknya akan membuat mereka mampu menghayati supremasi Kristus atas hidup mereka, atas alam semesta dan segala isinya.

\footnotetext{
${ }^{26}$ Soleman Kawangmani, Makin Berdoa Mantap Bermisi (Surakarta: Yayasan Gamaliel, 2020): 104-107.

${ }^{27}$ Soleman Kawangmani, "Aplikasi DialogisKlarifikatif Apologetika Paulus Terhadap Isu Gnostisisme Di Jemaat Kolose Bagi Generasi Milenial Yang Terpapar Zodiak Online," BIA': Jurnal Teologi dan Pendidikan Kristen Kontekstual 3, no. 2 (December 14, 2020): 145-166, http://www.jurnalbia.com/index.php/bia/article/view/17 1.
}

Pelaksanaan pemuridan korektif dengan memanfaatkan basis kelompok kekerabatan keluarga sangat kontekstual didukung dengan falsafah hidup suku Jawa yaitu 'mangan orang mangan asal kumpul. ${ }^{28}$ Hal mana akan efektif untuk mencapai pertumbuhan rohani secara kolektif sebagaimana yang dikehendaki Allah (Ef. 4:11-16).

\section{KESIMPULAN}

Pengenalan budaya suku Jawa melalui studi kasus keluarga Suk di Surakarta memiliki arti penting untuk merancang sebuah desain pemberitaan Injil yang kontekstual. Penelitian ini menemukan bahwa worldview sebagai inti budaya keluarga Suk bersuku Jawa adalah animisme dan "Desain Pemberitaan Injil-6P" dapat diterapkan untuk menjangkau keluarga Suk bagi Kristus.

Saran peneliti agar desain ini dapat diterapkan secara praktis kepada keluarga Suk maupun keluarga-keluarga suku Jawa lainnya yang menganut animisme untuk menguji efektivitas desain.

\section{KEPUSTAKAAN}

Creswell, John W. Penelitian Kualitatif Dan Desain Riset Memilih Di Antara Lima Pendekatan. Yogyakarta: Pustaka Pelajar, 2015.

Efi Nurwindayani. "Memperkenalkan Kerajaan Allah Untuk Suku Jawa." PASCA: Jurnal Teologi dan Pendidikan Agama Kristen 17, no. 1 (2021).

Geertz, Clifford. Abangan,Santri,Priyayi Dalam Masyarakat Jawa. Jakarta: Pustaka Jaya, 1983.

Haryono, Timotius. "Misi Kristus Di Bumi Jawa." Pengarah: Jurnal Teologi Kristen 3, no. 1 (2021).

Haryono, Timotius, and Attilovita Attilovita. "Model Komunikasi Kabar Keselamatan Kepada Aluk To Dolo Di Tana Toraja.” Fidei: Jurnal Teologi Sistematika dan Praktika

${ }^{28}$ Timotius Haryono, "Misi Kristus Di Bumi Jawa," Pengarah: Jurnal Teologi Kristen 3, no. 1 (2021). 
4, no. 1 (2021).

Hasselgrave, David J. Communicating Christ Cross-

Culturally. Malang: Literatur SAAT, 2013.

Herusatoto, Budiono. Simbolisme Dalam Budaya Jawa. Yogyakarta: PT Hanindita, 1987.

Hiebert, Paul G. Cultural Antropology. 2nd ed. Grand Rapids Michigan: Baker Book House, 1983.

Kawangmani, Soleman. "Aplikasi DialogisKlarifikatif Apologetika Paulus Terhadap Isu Gnostisisme Di Jemaat Kolose Bagi Generasi Milenial Yang Terpapar Zodiak Online.” BIA': Jurnal Teologi dan Pendidikan Kristen Kontekstual 3, no. 2 (December 14, 2020): $\quad$ 145-166. http://www.jurnalbia.com/index.php/bia/ article/view/171.

- Makin Berdoa Mantap Bermisi. Surakarta: Yayasan Gamaliel, 2020.

$\begin{array}{lr}\text { KONTEKSTUAL "POLA } & \text { APOLOGETIKA } \\ \text { MEMBERITAKAN KABAR } & \text { BNTUK } \\ \text { KEPADA SUKU JAWA WONG CILIK." } \\ \text { Jurnal Gamaliel: Teologi Praktika (2019). }\end{array}$

Koentjaraningrat. Kebudayaan Mentalitas Dan Pembangunan. Jakarta: PT Gramedia, 2002.

—. Manusia Dan Kebudayaan Di Indonesia. Jakarta: Penerbit Djambatan, 1987.

Kraft, Charles H. Antropology of Chistian Witness. Maryknol New York: Orbis Books, 1996.

Setiawan, David Eko. "Menjembatani Injil Dan Budaya Dalam Misi Melalui Metode Kontektualisasi." Fidei: Jurnal Teologi Sistematika dan Praktika 3, no. 2 (2020).

Siswanto, Krido. "Perjumpaan Injil Dan Tradisi Jawa Timuran Dalam Pelayanan Misi Kontekstual.” Evangelikal: Jurnal Teologi Injili dan Pembinaan Warga Jemaat 1, no. 1 (2017): 61.

Subagya, Rachmat. Agama Dan Alam Kerohanian Asli Di Indonesia. Jakarta: Cipta Loka Caraka, 1979.

Tomatala, Yakob. Pengantar Antropologi Kebudayaan: Dasar-Dasar Pelayanan Lintas Budaya. Jakarta: Media Penerbit Kristen, 2007.

Upacara Daur Hidup Daerah Jawa Tengah. Semarang: Depdikbud, 1984. 